DOI: $10.17805 / z p u .2016 .3 .24$

\title{
«Король Лир»У. Шекспира: переосмысление сюжета и вечных образов в русском и индийском литературном пространстве XIX века
}

\author{
Р. БАНЕРДЖИ
}

(УНИВЕРСИТЕТ ИМ. ДЖАВАХАРЛАЛА НЕРУ, Г. НЬЮ-ДЕЛИ, ИНДИЯ)

«Вечные образы» художественной литературы понимаются как своеобразная форма осмысления живой и актуальной действительности. Они отвечают универсальной потребности человека вести духовный поиск, размышлять над человеческой судьбой и общественными проблемами. В литературе XIX-XX вв. мы наблюдаем широко распространенное в литературах разных народов цитирование и переосмысление вечных образов из творчества английского писателя У. Шекспира. Среди наиболее популярных произведений отмечаются «Гамлет», «Ромео и Джульетта» и «Король Лир». В статье представлено исследование русской и индийской литератур XIX в., в которых отразилось использование и переосмысление сюжета и образов «Короля Лира».

В русской литературе шекспировское влияние заметно на произведениях А. Н. Островского («Свои люди - сочтемся»), И. С. Тургенева («Степной король Лир»), в индийской - Диджендролала Рая («Шахджахан»). Все они по-разному оценивали и воспринимали идеи Шекспира. «Степной король Лир» определяется как аллюзия или реминисценция. Это подсказывает необходимость ассоциативного восприятия этого произведения читателем. «Свои люди - сочтемся» является очевидной адаптацией, поскольку Островский стремился отобразить в образах сугубо реалистических, художественно-конкретных типичных представителей своей эпохи. «Шахджахан» также является адаптацией, ибо автор изменил сюжет и действующих персонажей, ориентируясь на спрос и понимание читательской аудитории своей страны.

Обобщаются аспекты, которые привлекли авторов к образам и сюжетам «Короля Лира»: драмы разворачиваются на фоне патриархального социально-экономического уклада, характерного для русского и индийского общества середины XIX в.; конфликт между отцами и детьми универсален по своей природе; идея изгнания как форма страдания оказалась привычной и понятной для индийского и русского менталитетов; понятным также был и сюжет о разделе имущества по решению главы семьи и последующих семейных раздорах. 
Основополагающей идеей произведений стала мысль Шекспира: власть и золото так же не вечны, как и все в этой земной жизни.

Ключевые слова: У. Шекспир; Лир; «Король Лир»; А.Н.Островский; И. С. Тургенев; Диджендролал Рай; шекспиризм; вечные образы литературы; русская литература ХІХ в.; индийская литература

\section{BВЕАЕНИЕ}

$\mathrm{H}$ ациональные культуры на различных этапах исторического развития вступали во взаимодействие друг с другом. В ходе этого процесса каждая вбирала самое значительное от другой, и более развитая культура обогащала менее развитую. Это относится и к литературе как важной и неотъемлемой части мировой культуры. Взаимосвязь и взаимодействие национальных литератур, которые приводят к обогащению каждой из них, всегда играли и продолжают играть огромную роль в истории всемирной литературы. Аля литературы XIX в. были свойственны активные межнациональные творческие контакты, причем в одних случаях они вели к взаимовлиянию, а в других - к одностороннему обогащению. В итоге национальные литературы развивались и совершенствовались. Это метко подметил в своих исследованиях советский ученый академик Н. И. Конрад: «Простирающаяся через века связь и преемственность образуют реальный субстрат всего литературно-исторического процесса» (Конрад, 1983: 20).

Значительную роль в этом процессе всегда играли так называемые вековые или вечные образы. Обращение к великим достижениям человеческого гения связано с глубинными законами восприятия традиционной культуры, ее сохранением, переосмыслением и постоянной актуализацией. В литературе XIX-XX вв. мы наблюдаем широко распространенное цитирование и иную интерпретацию «вековых» сюжетов и образов, в том числе шекспировских. Среди классических произведений великого английского писателя, к которым часто обращались авторы этой эпохи, можно отметить такие произведения, как «Гамлет», «Ромео и Ажульетта» и «Король $и$ и». Образы и сюжеты этих творений были использованы и переосмыслены не только в западной литературе, но и в творчестве писателей всех стран мира.

Целью данной статьи является анализ сюжета и вечных образов «Короля $\Lambda$ ра», которые переосмысливались в русской и индийской литературе XIX в. и приобретали в произведениях национальное наполнение и своеобразие.

\section{ВОСПРИЯТИЕ ШЕКСПИРА В РОССИИ И ИНАИИ}

Интерес к творчеству У. Шекспира в России появился в середине XVIII в., когда классик английской литературы был упомянут в «Эпистоле о стихотворстве» (1748 г.) А. П. Сумарокова в одном ряду прославленных поэтов прошлого. Вслед за Сумароковым обращались к Шекспиру Н. М. Карамзин, М. П. Вронченко и др.

Но особенно пристальное внимание к творчеству Шекспира стало проявляться в России в первые десятилетия XIX в. В это время увеличилось число шекспировских переводов, ставились его пьесы, ширился круг читателей и знатоков его творчества. Внимание многих русских писателей XIX в. привлекали реализм, свойственный творчеству Шекспира, яркие и рельефные образы его трагедий. Следует отметить, что в пробуждении интереса к английскому классику огромную роль 
сыграло творчество А. С. Пушкина, увлекавшегося, как известно, пьесами великого английского драматурга. Русский поэт считал Шекспира романтиком, понимая под «истинным романтизмом» новое искусство, соответствующее духу времени и глубоко отвечающее народным чаяниям. Ключевыми в творчестве Шекспира классик русской литературы считал объективность, жизненную правду характеров и верное отображение времени. Пушкин особо подмечал, что Шекспир «никогда не боится скомпрометировать свое действующее лицо - он заставляет его говорить со всей жизненной непринужденностью, ибо уверен, что в свое время и в своем месте он заставит это лицо найти язык, соответствующий его характеру» (Пушкин, 1962: 179-180).

К творчеству Шекспира в этот период обращались многие известные российские литературные критики, - например, В. Г. Белинский и Н. А. Аобролюбов. Первый писал в своих трудах о реализме, глубокой идейности, демократизме и гуманизме великого английского писателя. Симптоматично в этой связи одно из его замечаний: «Каждая его (Шекспира. - Р. Б.) драма есть мир в миниатюре» (Белинский, 1953: 32). В унисон с ним в оценке творчества Шекспира высказывался и Аобролюбов. Большое значение имеют такие его статьи, как «Темное царство» (1859), «Ауч света в темном царстве» (1860).

В ХХ в. творчество Шекспира пытался переосмыслить применительно к новой реальности Б. $\Lambda$. Пастернак. Среди литературоведческих работ на эту тему можно особо выделить труд под редакцией М. П. Алексеева «Шекспир и русская культура» (Шекспир и русская культура, 1965). В числе филологических исследований современного периода заслуживают упоминания работы шекспироведов Н. В. Захарова и Вл. А. Аукова (Захаров, Ауков, 2009) и переводы О. П. Сороки.

Иитературная общественность Индии обратилась к творчеству Шекспира приблизительно в то же время, как и в России, - в конце XVIII столетия. В то время страна была под британской оккупацией, и поэтому, наверное, нельзя считать случайностью, что знакомству индийцев с Шекспиром в немахой степени поспособствовали английские военнослужащие, проживавшие в стране.

Можно без преувеличения сказать, что шекспировская драматургия привлекла на том этапе внимание многих известных индийских писателей. Так, например, выдающийся бенгальский писатель Бонкимчондро Чоттопадхай (Bankim Chandra Chattapadhyay) много раз обращается в своих произведениях к образам, созданным английским классиком. Более того, он даже посвящает отдельную статью сравнительному анализу пьес английского драматурга и произведений Калидасы «Шакунтала, Миранда и Аездемона» (Shakuntala, Miranda, O Desdemona, 1887). Кроме того, в своей повести «Раджаны» (1877) он как бы призывает читателей к полемике вокруг трагических персонажей пьес Шекспира. Творчество английского писателя упоминается также во многих других его работах, таких как «Копал Кундола» (1866), «Камалакантер Аоптор» (1875) и пр. Известный драматург и писатель Бхартинду Харишчондро (Bhartendu Harishchandra) переводил и адаптировал шекспировские трагедии в 1870-1880 гг. и играл важную роль во вхождении в орбиту литературы и театра хинди трагедий Шекспира. Бенгальский драматург Гиришчондро Гхош (Girish Chandra Ghosh) разрабатывает шекспировский фантастический прием изображения действительности в своих исторических пьесах. 
Можно предположить, что творчество английского драматурга оказало существенное влияние на кумира литературного пространства Индии Рабиндраната Тагора (Rabindranath Tagore). Известно, что тринадцатилетний Тагор пытался переводить «Макбета» Шекспира и отзывался об английском писателе как о величайшем мастере трагедии. Взаимопроникновение различных культур и традиций находит и свое овеществленное выражение: в 1996 г. на родине Шекспира был воздвигнут памятник Рабиндранату Тагору с надписью - строками индийского поэта, посвященными великому английскому классику.

В конце XIX в. стали появляться переводы на разнообразные языки Индии, различные адаптации и переводы шекспировских трагедий для постановки на сцене. Популярность литературного творчества Шекспира продолжала возрастать в Индии и после обретения независимости. Скорее всего, это объяснялось тем, что его пьесы стали восприниматься общественностью как призыв к борьбе против социальной и экономической несправедливости и угнетения. Так, например, во второй половине XX в. известный актер, критик и писатель Утпол Аотто (Utpal Datta) многократно прибегал в своем творчестве к использованию шекспировских сюжетов и образов. Будучи одним из членов шекспировской театральной группы (Shakespeareana International Theatre Company), он пытался донести творчество Шекспира до широкой зрительской аудитории Индии, представив его трагедии в народной театральной форме «джатра».

K творчеству английского драматурга продолжают обращаться в Индии и по сей день. Следует отметить, что в 2013 г. в популярном театральном фестивале «Бхарот Рангмахотсав» (Bharat Rangmahotsav) были представлены шесть интерпретаций пьес Шекспира на разных национальных языках Индии. В последнее время шекспировские трагедии широко разрабатываются в адаптационной форме молодыми режиссерами, такими как Ритупорно Гхош (Rituporno Ghosh), Вишал Бхарадвадж (Vishal Bhardwaj) и др.

\section{ЗАИМСТВОВАНИЕ СЮЖЕТА И ОБРАЗОВ «КОРОАЯ АИРА}

Среди популярных шекспировских персонажей образ короля $\Lambda$ ира занимает особое место. Обращение к образу короля $\Lambda$ ира и его творческое переосмысление в литературах разных стран происходило под влиянием определенных исторических, социальных и культурных факторов, обусловленных быстрым ростом капиталистического производства. Шекспир, живший и творивший в эпоху первоначального накопления капитала, почувствовал и гениально выразил дух новой буржуазной эпохи. Эта проблема выпукло поставлена в трагедии «Король $\Lambda$ », в которой драматург показал, как золото разрушает общество, семью и душу человека. Поэтому трагический образ несчастного короля и его семьи стал своеобразной художественной моделью, которая использовалась в качестве «великого образа» многими писателями XIX-XX вв., наполняясь новым национальным содержанием. Ведь художественное воплощение вековых образов - это тот плацдарм, на котором ясно вырисовывается и традиционное, и новаторское в литературе.

Сюжет этой трагедии и рельефный образ короля Аира многократно использовались писателями и драматургами многих стран. В русской литературе к ним обращался А. Н. Островский в пьесе «Свои люди - сочтемся» (1850), И. С. Тургенев в повести «Степной король $\Lambda$ ир (1870), а также Н. Н. Златовратский в произведе- 
нии «Аеревенский Король Аир» (1880). К этой теме обращались и многие индийские писатели. Можно отметить пьесу «Сафед Кхун» Агхи Хасра Кашмири (Аgha Hasr Kashmiri) (1907), пьесу Аиджендролала Рая (Dwijendralal Roy) «Шахджахан» (1909) и некоторые другие. Интересен тот факт, что поэт и драматург Кашмири, который адаптировал многие пьесы Шекспира, был популярен как «Шекспир урду» ("Shakespeare of Urdu literature").

Анализ некоторых из этих произведений несомненно представляет большой интерес.

Особое внимание на образ короля Аира обратил в своем творчестве известный русский литературный критик Н. А. Аобролюбов. Анализируя причины человеческой трагедии короля Аира и его нравственного возрождения, он проводил мысль о зависимости психологии человека от его социального бытия. Ситуацию, в которой оказался английский вельможа, русский критик-демократ экстраполирует на родную ему русскую действительность XIX в., сопоставляя трагедию Аира с трагедией купца Большова из пьесы А. Н. Островского «Свои люди - сочтемся» (Аобролюбов, 1972). Общеизвестно, что Островский не только был знаком с творчеством Шекспира, но и занимался переводом пьесы английского драматурга «Усмирение своенравной» (The Taming of the Shrew).

Вслед за Шекспиром русский драматург XIX в. А. Н. Островский показывает страшную силу денег, разрушающую все естественные связи между людьми. Он также изображает распад семьи под влиянием денег, но только уже в другое время и другом обществе.

Герой Островского Самсон Силыч Большов - купец. Судя по всему, он принадлежит к старой породе московского купечества. Он деспотичен, груб, прямодинеен и простоват в обмане. Он управляет своей семьей так, что все в доме - от жены Аграфены Кондратьевны до слуги Тишки дрожат перед ним. Ощущение такой беспредельной власти над домашними согревает его душу. «Старая карга», «Убирайся к свиньям!», «Что ты рот-то разинул?» (Островский, 1970: 73) - так он обращается к домашним. Патриархальная психология подсказывает ему, что весь подлунный мир делится на чужих, которых нельзя не обманывать, и своих, которым самой природой определенно подчиняться его воле, пребывая в домашнем рабстве. На сопротивление жены против решения Большова выдать свою дочь замуж за Подхалюзина он реагирует так: «Мое детище: хочу с кашей ем, хочу масло пахтаю» (там же: 76). В его семье все отношения основаны на страхе и унижениях. 3десь нет ни взаимной любви, ни уважения к человеку. Большов не колеблясь обманывает своих кредиторов и, чтобы увеличить свой капитал, закладывает свой дом и лавки на имя своего приказчика и зятя Подхалюзина, надеясь, что его деньги останутся в его доме, в его распоряжении. Хотя Большов сам обманщик, он не верит, что свои люди могут обмануть его, и в этом его главная ошибка. Подхалюзин, в свою очередь, - обманщик даже в большей степени, чем Большов. После того, как кредиторы Большова посадили его в тюрьму, он просит Подхалюзина заплатить кредиторам по их требованиям. Но ни зять Подхалюзин, ни дочь Мипочка не соглашаются на это. Они оказались более бессовестными плутами, для которых нет ни своих, ни чужих, а только личный интерес. Это был большой удар для Большова.

Фигура Большова не просто смешна, она, скорее, трагична. Когда в последнем акте пьесы он выбирается из ямы, опозоренный и несчастный, так и хочется пожа- 
леть его как обманутого отца. Большов в отчаянии говорит: «Что вы! Что вы! Опо-

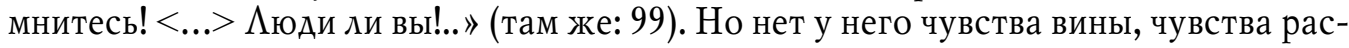
каяния.

Сопоставляя героя Островского с героем Шекспира, Аобролюбов отмечает: «В поступке Большова действительно есть внешнее сходство с поступком $\Lambda$ иа, но именно настолько, насколько может комическое явление походить на трагическое. Аир представляется нам также жертвой уродливого развития» (Аобролю-

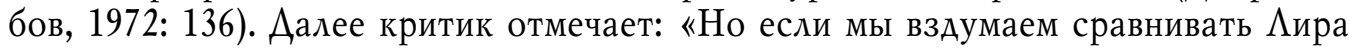
с Большовым, то найдем, что один из них с ног до головы король британский, а другой - русский купец; в одном все грандиозно и роскошно, в другом все хило, мелко, все рассчитано на медные деньги» (там же: 136-137).

Автор повести «Степной король Иир» И.С. Тургенев был хорошо знаком с культурой Европы. Одним из самых великих деятелей мировой литературы он считал Шекспира, о котором писал и образы которого использовал в своем творчестве. К 300-летию со дня рождения английского писателя появляется его статья об этом выдающемся драматурге «Праздник в честь Шекспира» (1864).

Говоря о творчестве Шекспира, Тургенев отмечал, что, когда исполнилось первое столетие со дня рождения классика, имя гения было почти забыто даже в родной для него стране. Англия в те годы только что выходила из-под власти пуритан, которые считали драматическое искусство развратом и запрещали сценические представление, а возвращение театра при Карле II не имело ничего общего с гуманистическим пафосом произведений Шекспира. Но уже через 200 лет Англия вновь открыла для себя своего поэта и стала гордиться им. Шекспир обрел немалую популярность и в Германии. Великие немецкие писатели XVIII в. Гете и $\Lambda$ ессинг переводили его произведения. А еще через век английский драматург стал известен всему миру, и теперь день его рождения празднуется во всех странах и на всех континентах.

И. С. Тургенев отмечал, что своими образами Шекспир покорил весь мир, во многом превзойдя в этом победы Наполеона и Юлия Цезаря. «Ни один образ не вырос так в последние сто лет, как образ Шекспира, - писал он, - и не будет конца его росту» (Тургенев, 1981a: 126). Аалее Тургенев пишет: «Мы празднуем его трехсотлетнюю годовщину, но мы уже ныне с уверенностью можем предсказать праздник его тысячелетия. Аа, подобно своему единственному сопернику, величайшему поэту древнего мира Гомеру, который, доживая свое третье тысячелетие, весь сияет блеском бессмертной молодости и неувядаемой силы, величайший поэт нового мира создан для вечности - и будет жить вечно. Мы, русские, празднуем память Шекспира, и мы имеем право ее праздновать. Аля нас Шекспир - не одно только громкое, яркое имя, которому поклоняются лишь изредка и издали: он сделался нашим достоянием, он вошел нашу плоть и кровь... Шекспир, как природа, доступен всем, и изучать его должен каждый сам, как и природу. Как она, он и прост, и многосложен, весь, как говорится, на ладони и бездонно глубок, свободен до разрушения всяких оков и постоянно исполнен внутренней гармонии и той неуклонной законности, логической необходимости, которая лежит в основании всего живого» (там же: $126-127)$.

Итак, мало сказать, что Тургенев высоко ценил Шекспира, - очевидно, что он восхищался великим драматургом. Этим чувством пронизаны многие его очерки 
и статьи, это явственно ощущается во многих его художественных произведениях, изобилующих перевоплощениями шекспировских образов.

В начале повести «Степной король $\Lambda$ и» Тургенев пишет от лица рассказчика: «Беседа зашла о Шекспире, об его типах, о том, как они глубоко и верно выхвачены из самых недр человеческой “сути”. Мы особенно удивлялись их жизненной правде, их вседневности; каждый из нас называл тех Гамлетов, тех Отелло, тех Фальстафов, даже тех Ричардов Третьих и Макбетов (этих последних, правда, только в возможности), с которыми ему пришлось сталкиваться» (Тургенев, 1981b: 159).

Тургенев особенно ценил шекспировских Гамлета и Аира. Он говорил, что, если бы вновь народился Шекспир, он никогда не отказался бы от своего Гамлета, от своего Аира. Очевидно, поэтому замысел написания Тургеневым «Степного короля $\Lambda$ иа» и «Гамлета Щигровского уезда» на тематической основе шекспировских трагедий возник не случайно. Обращаясь к образам Шекспира, он отразил в своих произведениях подлинные проблемы своей эпохи, наглядно выписал характеры русских людей своего времени, сопоставив их с «вековыми образами» мировой литературы.

Харлов, тургеневский «степной $\Lambda$ и», - это не король страны, а властитель своей маленькой державы. Но жизнь его так же трагична, как и жизнь его прототипа. Как и король из английской драмы, Харлов не может понять, что в мире, в котором он живет, деньги определяют законы и мораль общества, и в этом его трагедия. Ему, как и Аиру, приходится пройти трудный путь прозрения, понимания жизни и людей, что приводит его к трагическому финалу.

В начале повести мы видим героя повести Тургенева сильным и гордым человеком. Он чувствует себя потомственным русским дворянином, одним из тех, кто составляет основу нации, и воплощает в себе ее руководящее начало. Осознание своего благородного происхождения рождает в нем чувство собственного достоинства, уверенности в правоте. «Я - Харлов, фамилию свою вон откуда веду... (тут он показал пальцем куда-то очень высоко над собою в потолок) и чести чтоб во мне не было?! Аа как это возможно?!» — говорит он (там же: 161). Слово Харлова - закон для всех. Аочери Харлова, Анна и Евлампия, а также зять Слеткин заискивали перед ним, старались заботиться о нем. В самой натуре Харлова ощущается властность, порожденная русским крепостным бытом с его узаконенным и освященным вековой историей правом распоряжаться судьбой крестьян и судьбой своих близких. Отдавая имение своим дочерям, Харлов был уверен, что он отдает только имущественную сторону своей власти, сохраняя при этом духовное господство. При имущественном переделе своей собственности он проявляет свою власть и со-

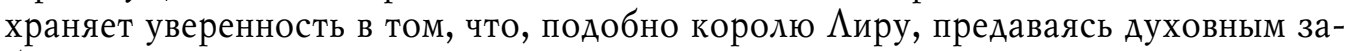
ботам, он сохранит почет и уважение. Его власть, считает он, держится не на том, что он хозяин собственности. Она основана, как ему представляется, на его приоритете старшего, главы семьи, дворянском достоинстве. «Против моей воли пойти? Аа в свете власти такой нет» - утверждает он (там же: 186).

Однако он ошибается. Повторяется история короля Аира. Зять и дочери отбирают у отца слугу Максимку, отнимают его экипаж. Харлов понимает, что он ошибся, что он не увидел за внешним проявлением чувств истинного отношения к себе каждой из дочерей. Он требует благодарности и повиновения. «Кланяйтесь»- слово, которое часто слышится из его уст во время церемонии, передачи 
имения, и дочери кланяются: Анна - в пояс, Евлампия - одной головой. Анна с видимым усердием, Евлампия - со столь же видимым напряжением. Но, как и в случае с королем Аиром, это только внешнее проявление благодарности, которое является взору Харлова; внутренний мир окружающих его людей остается для него скрытым.

Подобно Аиру, он становится нищим, меняется его характер, исчезают гордость, самоуверенность, появляется самокритичность. Он говорит: «Больше всех виноват я сам. <...> Гордость погубила меня» (там же: 207). Эта фраза напоминает знаменитое изречение короля $\Lambda$ ира об отсутствии виноватых в этом мире.

Можно таким образом сказать, что в «Степном короле $\Lambda$ ие» автором смоделирована типично шекспировская ситуация (уже сам факт раздела имения при жизни его владельца), но раскрывается она применительно к новым условиям жизни, в контексте иных национальных и моральных реалий.

Моральный крах Харлова, как и его прототипа короля $\Lambda$ ира, связан с низвержением его надежд и иллюзий, приведших обоих героев к гибели.

Шекспировская тематика, как уже отмечалось, оказалась глубоко созвучной творчеству многих индийских писателей. В своих произведениях к ней постоянно обращался, например, известный драматург XIX в. Аиджендролал Рай (Dwijendralal Roy), который, воспевая английского мастера слова, отметил, что европеец и смуглый ариец, живущий в далеком краю на берегу Ганги, будут восхищаться им (Roy, 1984: 64). Следует, однако, отметить, что в реинтерпретации сюжетов английского классика, в том числе «Короля $\Lambda$ ира, бенгальский драматург Рай шел не от сюжета классической трагедии, а от глубинного заложенного в ней смысла человеческого деспотизма, одержимости властью, стяжательства и как следствие этих человеческих пороков - конфликта отцов и детей, приводящего к разрушению как семейного мира, так и всего государства в целом.

Автор этого произведения переносит ситуацию, в которой оказался король $\Lambda$ ир, на историческую действительность периода монгольского владычества в Ин-

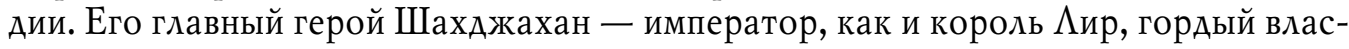
титель державы. Начало повествования выглядит драматичным: владыке не верится, что его родной сын Аурангзеб лишил его свободы. Ему не хочется думать о том, что он, хозяин великой страны, слова которого были законом для всех, оказался бесправным узником. Подумать страшно: его собственный сын, который всегда страшился отца, теперь стал его повелителем. Однако император все еще верит в постоянство и прочность патриархального уклада. Он гордый деспот и поэтому восклицает: «Я царь Шахджахан, который долго так властвовал над Индией» (ibid: 21). Он верил, что его призыв сплотит его народ и вместе они повергнут в прах сотни таких Аурангзебов. Напоминая о том, что является действующим императором страны, он выражает уверенность в том, что его подданные по-прежнему чтят его столь же высоко, сколь и ранее. Определяя Аира, Аобролюбов говорил, что «поступок его, полный гордого сознания, что он сам, сам по себе велик, а не по власти, которую держит в своих руках» (Аобролюбов, 1972: 136). Это замечание Аобролюбова в полной мере можно отнести и к Шахджахану. Его прекраснодушной иллюзии суждено было рухнуть столь же скоро, как и у короля Аира и Харлова. Так же, как и они, униженный император осознает, что создатель этого грешного мира - не кто иной, как он сам. 
Концовка повествования у Рая, впрочем, отличается от классических канонов. В отличие от известных в мировой литературе сюжетов заговорщик, мятежный сын Аурангзеб осознает свою вину и раскаивается.

Аействующие лица пьесы Рая, схожие с персонажами из известной трагедии Шекспира, воплощают в себе всю гамму человеческих эмоций, от немыслимой жестокости до милосердия и гуманности, в чем они отличаются от персонажей Тургенева и Островского, сохраняя все лучшие человеческие качества при любых жизненных испытаниях, которыми держится мир. Образ Ажаханары, дочери Шахджахана, во многом напоминает образ Корделии - благородная, честная, она считает своим долгом заботиться об отце. Аара, второй сын императора, похож на шекспировского Эдгара, борющегося за истину, тогда как мудрый Аилдар ассоциируется с образом Шута.

Типологические и сюжетные сходства, таким образом, очевидны. Можно поэтому с большой долей уверенности утверждать, что индийский драматург Рай, творя в духе Шекспира, создавал, основываясь на национальной и исторической почве, оригинальную социально-философскую трагедию, тяготея вместе с тем к обобщенным образам, содержащим в себе не только национальные, но и общечеловеческие и общекультурные ценности.

Очевидно, таким образом, что тематика, затронутая в произведениях классиком английской литературы, оказалась глубоко созвучной, близкой и понятной людям, проживающим в самых разных уголках нашей планеты. Поэтому не случайно в произведениях писателей и драматургов, творящих на разных языках и проживающих на различных континентах, повторяются сюжеты, напоминающие историю короля Аира, семьи Харлова, Большова и Шахджахана. Проблема, затронутая гением английской литературы, имеет универсальный и вневременной характер. Власть денег разрушает семейные отношения, одержимость стяжательством ведет к моральному распаду личности.

Тем не менее толкование этой проблемы их создателями и отношение их к своему герою остаются различными. У И. С. Тургенева и А. А. Рая, как и у Шекспира, это трагедия человека, осознавшего свою вину. Аир-король у Шекспира, Шахджахан-император у Рая, Харлов-помещик у Тургенева - все они трагичны, поскольку осознают несправедливость, аморальность своей собственной жизни, своей семьи и жестокость того мира, который сами создали. Представитель московского купеческого мира Большов совершенно не способен к такому гуманизму и философскому осмыслению жизни. Он как продукт той среды, где принцип голого чистогана стал основой жизни общества и фундаментом новой морали, был готов обмануть всех. Обман для него - формула жизнедеятельности. Если нет обмана, то нет его как купца, как деятеля, как почитаемого члена купеческого сословия. Он, в отличие от шекспировского короля, Харлова или Шахджахана, не чувствует никаких угрызений совести: ведь так поступают все. Поэтому, в отличие от Шекспира, Островский показывает проблему распада семьи и человеческой личности под влиянием денег не в трагическом, а в комическом плане, широко используя все формы комического (от юмора до злой сатиры).

Можно также предположить, что вышеуказанные авторы, которые так или иначе обращались в своем творчестве к сюжетам и образам великого Шекспира, по-разному оценивали и воспринимали его творчество. Так, например, «Степной 
король $\Lambda$ ир И. С. Тургенева можно определить как аллюзию или реминисценцию, что подсказывает необходимость ассоциативного восприятия этого произведения читателем. Заглавие повести Тургенева прямо указывает, что в ней речь пойдет о русском варианте героя великой трагедии Шекспира. «Свои люди - сочтемся» А. Н. Островского является очевидной адаптацией, поскольку Островский стремился отобразить в образах сугубо реалистических, художественно-конкретных типичных представителей своей эпохи. Само название комедии имеет иронический смысл. Герои далеки от народной мудрости и морали, они живут по принципу «человек человеку - волк». Он уделяет пристальное внимание изображению быта и нравов купеческого мира России и тем самым вносит в свою пьесу элемент русификации, т. е. русский колорит.

«Шахджахан» Аиджендролала Рая также является адаптацией, ибо автор изменил сюжет и действующих персонажей, ориентируясь на спрос и понимание читательской аудитории своей страны.

\section{ЗАКАЮЧЕНИЕ}

Вечные образы зачастую предстают в своеобразной форме осмысления повседневной действительности. Они побуждают оценить сегодняшний день в широкой перспективе духовных извечных исканий человечества, вдуматься в судьбу человека и мира в масштабах тысячелетнего опыта и в контексте мировой истории. Стремление к такому идеалу особенно наглядно проявляется на примере обращения к творчеству Шекспира, характерного для русской и индийской литературы XIX в.

Основываясь на классическом шекспировском сюжете, писатели разных континентов блистательно отразили социальные и нравственные конфликты, характерные для своих стран периода середины XIX в.: А. Н. Островский в форме бытовой комедии (семья купца Самсона Силыча Большова), И. С. Тургенев в форме реалистической повести (семья помещика Мартына Петровича Харлова), Аиджендролал Рай в форме исторической пьесы (семья царя Шахджахана).

Что же конкретно привлекало русских и индийских писателей и представителей изобразительных искусств к образам и сюжетам «Короля $\Lambda$ ира» Шекспира? С определенной долей условности можно попытаться ответить на этот непростой вопрос. Во-первых, драма Шекспира разворачивается на фоне патриархального социально-экономического уклада, характерного для русского и индийского общества середины XIX в. Во-вторых, конфликт между отцами и детьми универсален по своей природе, он отмечается в любом обществе, особенно в переходные между формациями периоды, когда старые ценности вступают в конфликт с новыми. В данном контексте это феодальные патриархальные нормы, приходящие в столкновение с новыми капиталистическими буржуазными понятиями, где всем в жизни управляют деньги и власть. В-третьих, идея изгнания как форма страдания оказалась привычной и понятной для индийского и русского менталитета. В-четвертых, сюжет о разделе имущества по решению главы семьи и последующих семейных раздорах, которые за ним неизбежно следуют, оказался созвучным и понятным многим. И наконец, самое главное - основополагающей истиной навсегда останется мысль Шекспира: власть и золото так же не вечны, как и все в этой земной жизни. 
Шекспировский «Король $\Lambda$ ир и другие трагедии стали и навсегда останутся неотъемлемой частью литературы разных наций и несомненно, как утверждают Н. В. Захаров и В. А. Ауков, Шекспир - «самый успешный писатель и драматург, равно принадлежащий всему миру...» (Захаров, Ауков, 2009: 99). В своем стихотворении Тагор пишет:

Сегодня - как повсюду -

С индийских берегов, где пальм ряды растут, Меж трепетных ветвей тебе хвалу поют.

(Пер. А. А. Ахматовой)

Поэтическое воображение Тагора о Шекспире отзывается в разных формах в разных концах мира. Широкое толкование шекспировской трагедии в сфере литературы, музыки, изобразительного искусства, театра и кино и в сегодняшние дни подтверждает это.

\section{СПИСОК АИТЕРАТУРЫ}

Белинский, В. Г. (1953) Иитературные мечтания // Белинский, В. Г. Полн. собр. соч. : в 13 т. М. : Изд-во АН СССР. Т. 1. Статьи и рецензии. Художественные произведения. $1829-1835.574$ с. С. $20-104$.

Аобролюбов, Н. А. (1972) Темное царство (Сочинения А. Островского. Ава тома. СПб., 1859) // Аобролюбов, Н. А. Статьи. Стихотворения. М. : Московский рабочий. 456 с. C. $88-231$.

Захаров, Н. В., Ауков, В. А. (2009) Шекспир и шекспиризм в России // Знание. Понимание. Умение. № 1. С. 98-106.

Конрад, Н. И. (1983) Введение (1. Место первого тома «В истории всемирной литературы») // История всемирной дитературы : в 9 т. / гл. ред. Г. П. Бердников. М. : Наука. Т. 1 / отв. ред. И. С. Брагинский. 584 с. С. 14-20.

Островский, А. Н. (1970) Избранные пьесы. М. : Художественная дитература. 464 с.

Пушкин, А. С. (1962) Н. Н. Раевскому-сыну // Пушкин, А. С. Собр. соч. : в 10 т. М. : Художественная литература. Т. 9: Письма. 1815-1830. 494 с. С. 179-180.

Тургенев, И. С. (1981а) Статьи и воспоминания / сост. А. А. Шавкута. М. : Современник. 303 с.

Тургенев, И. С. (1981b) Степной король Иир // Тургенев, И. С. Полн. собр. соч. и писем : в 30 т.; Соч. : в 12 т. 2-е изд., испр. и доп. М. : Наука. Т. 8: Повести и рассказы, $1868-1872.544$ c. C. $159-227$.

Шекспир и русская культура (1965) / под ред. М. П. Алексеева. М. ; А. : Наука. 831 с. Roy, D. L. (1984) Shahjahan. 2nd edn. Calcutta : Pustak Biponi. 93 р. (На бенг. яз.).

Аата поступления: 15.07.2016 2.

\section{REINTERPRETATIONS OF SHAKESPEAREAN TIMELESS PLOT AND IMAGERY IN RUSSIAN AND INDIAN CULTURAL SPACE IN THE 19TH CENTURY: \\ "KING LEAR" RANJANA BANERJEE \\ (Jawaharlal Nehru University, NeW Delhi, India)}

'Timeless images' of literature should be understood as a kind of apprehension of the living reality. They are born out of mankind's universal need for spiritual improvement, a desire to 
reflect on human destiny and social issues. The 19 th- and 20th-century literary process is characterized by active multinational literary contacts, leading to unilateral or bilateral influences. Referring to literary masterpieces of the past in order to reassess the present is a common trend. Thus in the literature of these two centuries we find a lot of references to Shakespearean imagery. Among them, the most popular are the ones that come from "Hamlet", "Romeo and Juliet" and "King Lear". In this article, we look at how the images and plot of "King Lear" were reused and reinterpreted in Russian and Indian literature of the 19th century.

The storyline and imagery of "King Lear" are traced in the works of various writers: in Russian literature: it is Alexander Ostrovsky ("It's a Family Affair - We'll Settle It Ourselves"), Ivan Turgenev ("King Lear of the Steppe"), in Indian (Bengali) literature - Dwijendralal Roy ("Shahjahan"), to name but a few. Each of the authors had their own take on Shakespeare's work. "King Lear of the Steppe" as an extended allusion calls for an associative reading. "It's a Family Affair..." is obviously an adaptation of Shakespearean plot, since Ostrovsky strived to describe in a realist manner typical characters of his times. "Shahjahan" is another example of an adaptation where the author modified the plot and characters to fit the demands and views of contemporary audience.

At the same time, Russian and Indian authors' interest in "King Lear" shares a number of common aspects: dramas are set in patriarchal societies of mid-19th century; the parents-children conflict is presented as timeless and universal; the idea of exile as suffering is familiar for both Russian and Indian mentalities, as well as the father's decision to divide the estate as the starting point of a subsequent family quarrel.

The underlying idea of all of these texts is Shakespeare's view of power and gold as things no less transitory than anything else on Earth.

Keywords: William Shakespeare; Lear; "King Lear"; Alexander Ostrovsky; Ivan Turgenev; Dwijendralal Roy; Shakespeareanism; timeless characters; 19th-century Russian literature; Indian literature

\section{REFERENCES}

Belinsky, V. G. (1953) Literaturnye mechtaniia. In: Belinsky, V. G. Polnoe sobranie sochinenii : in 13 vols. Moscow, Publ. House of the Academy of Sciences of the USSR. Vol. 1: Stat'i i retsenzii. Khudozhestvennye proizvedeniia. 1829-1835. 574 p. (In Russ.).

Dobroliubov, N. A. (1972) Temnoe tsarstvo (Sochineniia A. Ostrovskogo. Dva toma. SPb., 1859). In: Dobroliubov, N. A. Stat'i. Stikbotvoreniia. Moscow, Moskovskii rabochii Publ. 456 p. Pp. 88-231. (In Russ.).

Zakharov, N. V. and Lukov, V. A. (2009) Shekspir i shekspirizm v Rossii. Znanie. Ponimanie. Umenie, no. 1, pp. 98-106. (In Russ.).

Konrad, N. I. (1983) Vvedenie (1. Mesto pervogo toma «V istorii vsemirnoi literatury»). In: Istoriia vsemirnoi literatury : in 9 vols. / ed. by G. P. Berdnikov. Moscow, Nauka Publ. Vol. 1 / ed. by I. S. Braginskii. 584 p. Pp. 14-20. (In Russ.).

Ostrovsky, A. N. (1970) Izbrannye p’esy. Moscow, Khudozhestvennaia literature Publ. 464 p. (In Russ.).

Pushkin, A. S. (1962) N. N. Raevskomu-synu. In: Pushkin, A. S. Sobranie socbinenii : in 10 vols. Moscow, Khudozhestvennaia literature Publ. Vol. 9: Pis'ma. 1815-1830. 494 p. Pp. 179-180. (In Russ.).

Turgenev, I. S. (1981a) Stat' $i$ i vospominaniia / comp. by A. D. Shavkuta. Moscow, Sovremennik Publ. 303 p. (In Russ.).

Turgenev, I. S. (1981b) Stepnoi korol' Lir. In: Turgenev, I. S. Polnoe sobranie socbinenii $i$ pisem : in 30 vols. : Sochineniia : in 12 vols. 2nd edn., revised and enlarged. Moscow, Nauka Publ. Vol. 8: Povesti i rasskazy, 1868-1872. 544 p. Pp. 159-227. (In Russ.). 
Shekspir i russkaia kul'tura (1965) / ed. by M. P. Alekseev. Moscow ; Leningrad, Nauka Publ. 831 p. (In Russ.).

Roy, D. L. (1984) Shabjaban. 2nd edn. Calcutta, Pustak Biponi. 93 p. (In Bengali).

Submission date: 15.07.2016.

Банерджи Ранджана - PhD, профессор Центра русских исследований Университета им. Ажавахарлала Неру. Адрес: Центр русских исследований, каб. 325, Университет им. Ажавахарлала Неру, г. Нью-Аели, Индия, 110067. Тел.: (+91) 9811368573, (+91) 2674-1402. Эл. aApec: ranjanab1992@gmail.com, ranjanab_5@yahoo.co.in

Banerjee Ranjana, PhD, Professor, Centre of Russian Studies, Jawaharlal Nehru University, India. Postal address: Centre of Russian Studies, Office 325, Jawaharlal Nehru University, 110067 New Delhi, India. Tel.: (+91) 9811368573, (+91) 2674-1402. E-mail: ranjanab1992@ gmail.com,ranjanab_5@yahoo.co.in 